\title{
Letter to the President from the Chief Medical Officer, Department of Health
}

Thank you for your letter of 30 October in which you raise two possible problems that are causing concern to your College Examination Sub Committee.

I apologise for the delay in replying to your letter, but I am now in a position to deal with the questions you have raised.

With regard to the possibility of Health Authorities charging the College for use of clinical facilities which the College needs to conduct examinations, I would consider it reasonable to expect Units to waive charging for the use of an examination centre. The Steering Group on Undergraduate Medical and Dental Education recommended, with the endorsement of the Secretaries of State for Health, and Education, that the NHS and Universities should be discouraged from charging one another.

It would be hoped that NHS units would adopt a similar stance with regard to charging for facilities made available to further postgraduate medical education. It is worth emphasising that units, and the service, benefit ultimately from medical education undertaken by their staff.
The question of study leave and the employing authority being reluctant to allow time for your Members and Fellows to conduct examinations is covered by the rules governing study leave as laid down in paragraphs 250 to 252 of the Terms and Conditions of Service. This makes it clear that examining falls within the study leave entitlement of the practitioner, and that an employing authority is able to grant additional periods of study leave in circumstances where there would be a benefit to the long term needs of training and professional development of the practitioner.

In addition each consultant can agree with their local general manager to have their examining responsibilities recognised as part of their NHS work under their contract of employment. All hospital consultants would now have job plans agreed with their general manager as set out in $\mathrm{HC}(90) 16$.

I hope that through the mechanisms outlined above, it will be possible for these potential problems to be successfully avoided.

Dr Kenneth C. Calman

\section{Obituary}

Editor: Henry R. Rollin

George Kerr, formerly Consultant Psychiatrist and Medical Administrator, Dovenby Hall Hospital, Cockermouth, Cumbria and Director of the National Development Team for Mentally Handicapped People

George Kerr died aged 56 on 3 August 1991 from multiple sclerosis, the illness which dogged his professional career and forced his early retirement in 1986. A founder member of the College, he was elected to the Fellowship in 1980.

George entered the field of mental handicap at a time of great change. He was a passionate believer in modern philosophies and a champion of normalis- ation, care in the community and teamwork - goals which he worked tirelessly to achieve in his clinical posts and in his work at the Department of Health and Social Security. Caring and sensitive and with a quiet energy, he had little difficulty in carrying staff with him. Under his guidance, Earls House Hospital became a model service and in Cumbria, well before it became national policy, he pioneered the resettlement of residents from Dovenby Hall Hospital into integrated community care programmes based on small homes and community teams. The Aldingham Project, as this was known, was runner up in the Health and Social Services Journal Joint Care Award for 1981-82. 
A native of Cumbria, George was educated at Whitehaven Grammar School where he was House Captain and Head Boy. He received his medical training at Bristol University and Medical School (MB ChB 1959) and was for a time President of Galenicals (the Medical Students Union) After early jobs in medicine and neurology he entered psychiatry in 1962 as a Junior Hospital Medical Officer at Dovenby Hall Hospital, proceeded to registrar training in Sunderland and Newcastle and then to Prudhoe and Northgate Hospitals for senior registrar training.

His first consultant post was at Earls House Hospital, Durham, (1968-1971), where he presided over an extensive modernisation and rebuilding programme and was instrumental in establishing services on a firm modern footing. In 1971 he was appointed Senior Lecturer in the Department of Psychiatry, Southampton University, one of the first academic posts in the specialty to be established and Consultant Psychiatrist to Coldeast Hospital, Southampton. From 1973 he combined this with a part-time appointment as Specialist Adviser in Mental Handicap to the Department of Health and Social Security which involved him in a punishing schedule of daily commuting. He opted for full-time clinical work - his real forte, again in 1975 when he was appointed Consultant Psychiatrist and Medical Administrator at Dovenby Hall Hospital where, over the next ten years largely single-handedly and with characteristic energy and enthusiasm, he set about modernising services for the mentally handicapped in East and West Cumbria.

From 1975 to 1977 he was a member of the Jay Committee on Nursing and the Care of the Mentally Handicapped. In 1984 he eagerly accepted the appointment of Director of the National Development Team for Mentally Handicapped People, seeing this as a further opportunity to contribute his vision and expertise at a national level. Sadly this was not to be. Failing health forced him to retire from the post after only nine months and shortly afterwards from professional work altogether.

George bore the illness which began when he was a medical student with great courage and fortitude. He faced death with equal courage, helping to plan his own funeral. He is survived by his wife, Naomi, a general practitioner in Cumbria, who provided untiring support throughout his career, and their two children whose achievements and individuality gave him much pride and pleasure.

\section{KenNETH DAY}

\section{John Paul Mellon, formerly Consultant for the Mental Handicap Service in Tayside and Honorary Senior Lecturer, University of Dundee}

Dr John Mellon died on 3 August 1991, after a short illness. He was born in 1930 and educated at St Aloysius College, Glasgow. He attended Glasgow University and qualified $\mathrm{MB} \mathrm{ChB}$ in 1956. After house officer jobs in Glasgow he began psychiatric training at the Glasgow Royal Mental Hospital. In 1959 he moved to Dundee as registrar in psychiatry and following this began to take an increasing interest in mental handicap. He became a senior registrar at Strathmartine Hospital, Dundee, in 1961 and was promoted to consultant there in 1964 . He remained in this post until the time of his death.

John Mellon was always deeply committed to the treatment and care of those suffering from mental handicap and had a wide knowledge of the subject and his patients. During the last 20 years of his career, he was particularly concerned with services to Perth and Angus and he held regular clinics in various parts of the counties. Always a firm believer in the importance of the medical and psychiatric role in mental handicap, John also worked increasingly with other agencies and professions. He published scientific papers on various aspects of mental handicap including Down's syndrome and thyroid antibodies as well as chromosome surveys. He undertook research into various aspects of phenylketonuria and developed and managed a chromatography unit at Strathmartine Hospital until this work was transferred to Glasgow. He was involved in the Mental Handicap Section of the College and was elected Scottish Vice-Chairman in 1972.

Besides his medical work, John had various other interests including old Scottish tombstones about which he wrote a book. He was an enthusiastic fisherman who made his own flies and greatly enjoyed working in his garden. In recent years he regularly visited Spain where his daughter had settled.

John Mellon will be greatly missed by staff, colleagues and patients. He is survived by his wife May, formerly a general practitioner in Dundee, and two daughters and a son.

Brian R. BALlinger 